\title{
The practice of farming, processing and trading of tobacco by Sukasari people of Sumedang District, West Java, Indonesia
}

\author{
JOHAN ISKANDAR ${ }^{1,2}$, BUDIAWATI S.ISKANDAR ${ }^{3}$, AZRIL $^{1}$, RUHYAT PARTASASMITA $^{1, \bullet}$ \\ ${ }^{1}$ Department of Biology, Faculty of Mathematics and Natural Sciences, Universitas Padjadjaran. Jl. Raya Bandung-Sumedang Km 21, Jatinangor, \\ Sumedang 45363, West Java, Indonesia. Tel.: +62-22-77912. `email: ruhyat.partasasmita@unpad.ac.id, rp2010rikkyo@gmail.com \\ ${ }^{2}$ Postgraduate of Environmental Science (PSMIL \& DIL) and Institute of Ecology (PPSDAL), Universitas Padjadjaran. Jatinangor, Sumedang 45363, \\ West Java, Indonesia \\ ${ }^{3}$ Department of Anthropology, Faculty of Social and Political Science, Universitas Padjadjaran. Jatinangor, Sumedang 45363, West Java, Indonesia
}

Manuscript received: 20 March 2017. Revision accepted: 30 September 2017.

\begin{abstract}
Iskandar J, Iskandar BS, Azril, Partasasmita R. 2017. The practice of farming, processing and trading of tobacco by Sukasari people of Sumedang District, West Java, Indonesia. Biodiversitas 18: 1517-1527. Tobacco (Nicotiana tabacum L) is an original crop of Cuba, Latin America, discovered by Christoper Columbus in 1492 and introduced to Europe. Moreover, it was distributed to Asia countries, including Indonesia. Local people of Sukasari village, Sukasari sub-district, Sumedang district, West Java, has cultivated tobacco for a long time, since the Dutch colonial, based on local ecological knowledge transmitted by inter-generations. As a result, local people of Sukasari village have rich knowledge on the tobacco. Nowadays, however, since the agricultural lands as well as tobacco farmers have decreased, the local ecological knowledge of the Sukasari people have eroded. This paper elucidates the local ecological knowledge of Sukasari people, Sumedang District of West Java on landraces, cultivation, process, and local trading of tobacco. The method used in this study was qualitative with descriptive analysis applying the ethnoecological approach. The result of the study showed that the Sukasari people have predominantly cultivated four landraces of the tobacco. The cultivation of tobacco include the selecting of seeds, nursery, preparing land, planting, caring, harvesting and processing of tobacco products, requiring diligent efforts and high skill. Today, the cultivation of tobacco has many constrains, such as climate anomalies, decrease of agricultural lands, and the lack of finance; consequently, the tobacco farmers have less enthusiasm to cultivate the tobacco. As a result of decreaase of tobacco cultivation, the local ecological knowledge of the Sukasari people has eroded and may extinct in the near future.
\end{abstract}

Keywords: tobacco, local ecological knowledge, Sumedang

\section{INTRODUCTION}

Tobacco (Nicotiana tabaccum L.) is an original crop of Cub, Latin America, discovered by Christoper Columbus in 1492 (Cotton 1996). It was introduced to Europe and later distributed to Asian countries. According to Arnez (2009), tobacco was introduced to Asia in 1575, when the Spanish brought it to the Philippines from Mexico, and in 1601 it was introduced to Java. Moreover, the tobacco has been farmed in some places of Java, including West, Central, and East Java (Geertz 1963; Elson 1994; Boomgard 2002; Djajadi 2015). In West Java, this crop have been traditionally farmed by village farmers in some district areas of Sumedang, Bandung, Garut, Majalengka, and Cirebon (Igarashi 1985; Elson 1994; Boomgard 2002; Alamsyah 2011; Cakrabawa and Nuryati 2014; Djajadi D 2015).

Farmers of Sukasari Village, Sukasari Sub-district, Sumedang District, West Java, have traditionally farmed tobacco for a long time, since the Dutch colonial. They have cultivated tobacco in the dry land, based on the local ecological knowledge which is transmitted from generation to generation through three main general stages, namely parental, peer, and individual learning (cf. Puri 1997). Tobacco has been planted mostly in the dry land. Furthermore, the production leaf of tobacco has been processed by farmers to be special tobacco called tembakau rakyat or bako mole (Alamsyah 2011). The bako mole has been sold to village middlemen, local traditional market or cigarette factories.

The cultivation of tobacco and tobacco leaf processing to bako mole undertaken by each hold of tobacco farmers has been based on the local ecological knowledge which is strongly embedded in local tradition. The local ecological knowledge or traditional ecological knowledge, indigenous knowledge, folk knowledge is different from Western Knowledge, in that it istransmitted by oral, teaching through doing, experiential, diachronic, holistic, and vulnerable to extinction (Ellen 2002; Sillitoe 2002). Although the local ecological knowledge has many terms, but in general it may be defined it as "cumulative body of knowledge, practice, and belief, evolving by adaptive process and handed down through generations by cultural transmission, about the relationships of living being (including humans) with one another and with their environment" (Bereks et al. 2000). The local knowledge is traditionally obtained based on the close interrelationships between people with a sustainable local environment for a long time (cf. Fowler 2000; Ford 2000). As a result, generally the local knowledge on tobacco farming and its production processing are traditionally obtained by tobacco farmers who have been intensively involved in the tobacco 
farming for generations. The cultivation of tobacco in the Sukasari Village has been influenced by many factors, particularly the ecological, local ecological knowledge, and socio-economic village people (cf. Mitchell 2006; Karim 2016; Iskandar et al. 2016). The local ecological knowledge of the tobacco farming, particularly the processing of tobacco to bako mole has traditionally been owned by the male gender. Moreover, this knowledge is traditionally inherited to their sons. Therefore, if the farmers household does not have any son, the tobacco farming rarely is continued. In addition, as of today, the cultivation of tobacco has many constraints, such as climate anomalies, the decrease of agricultural lands, the lack of finance, also fluctuation of input and output prices; consequently, the tobacco farmers suffer less enthusiasm to cultivate the tobacco. Indeed, the local ecological knowledge of the Sukasari people has eroded and may come to extinction in the near future.

The paper elucidates cultural practices among the Sukasari People of Sukasari Village, Sumedang, West Java, on tobacco farming, particularly regarding the local ecological knowledge on tobacco variations, traditional farming, and tobacco trading.

\section{MATERIALS AND METHODS}

\section{Study area}

Administratively, Sukasari Village is recorded as one of seven villages of the Sukasari Sub-district (prior to 2001 registered as Tanjungsari sub-district), Sumedang District, West Java. Geographically, Sukasari Village is located at approximately $179^{\circ} 47^{\prime} 16.5164^{\prime \prime} \mathrm{E}$ and $6^{\circ} 52^{\prime} 35.0261^{\prime \prime} \mathrm{S}$ (Figure 1).This village is located between 8 masl and 1,040 $\mathrm{m}$ asl (above sea level) which has a hilly landscape. The Sukasari village has a total of about 438 hectares. About 157 hectares of the land is devoted to the wet-rice field, on the other hand 212 hectares is devoted to the dry land field, then a further 69 hectares has other land-uses (Pemdes Sukasari 2016). The Sukasari is a village that lies northeast of Bandung city and west of Sumedang District. To the north it is bordered by Kadakajaya Village; to the south it is bordered by Mekarsari Village; to the west it is bordered by Genteng village; and to the east it is bordered by Margaluyu Village.Reaching Sukasari Village by public transportation is considered to be quiet easy. Embark by bus or 'angkot' from Bandung city to the Grand Mosque (Masjid Agung) of Tanjungsari Sub-district with
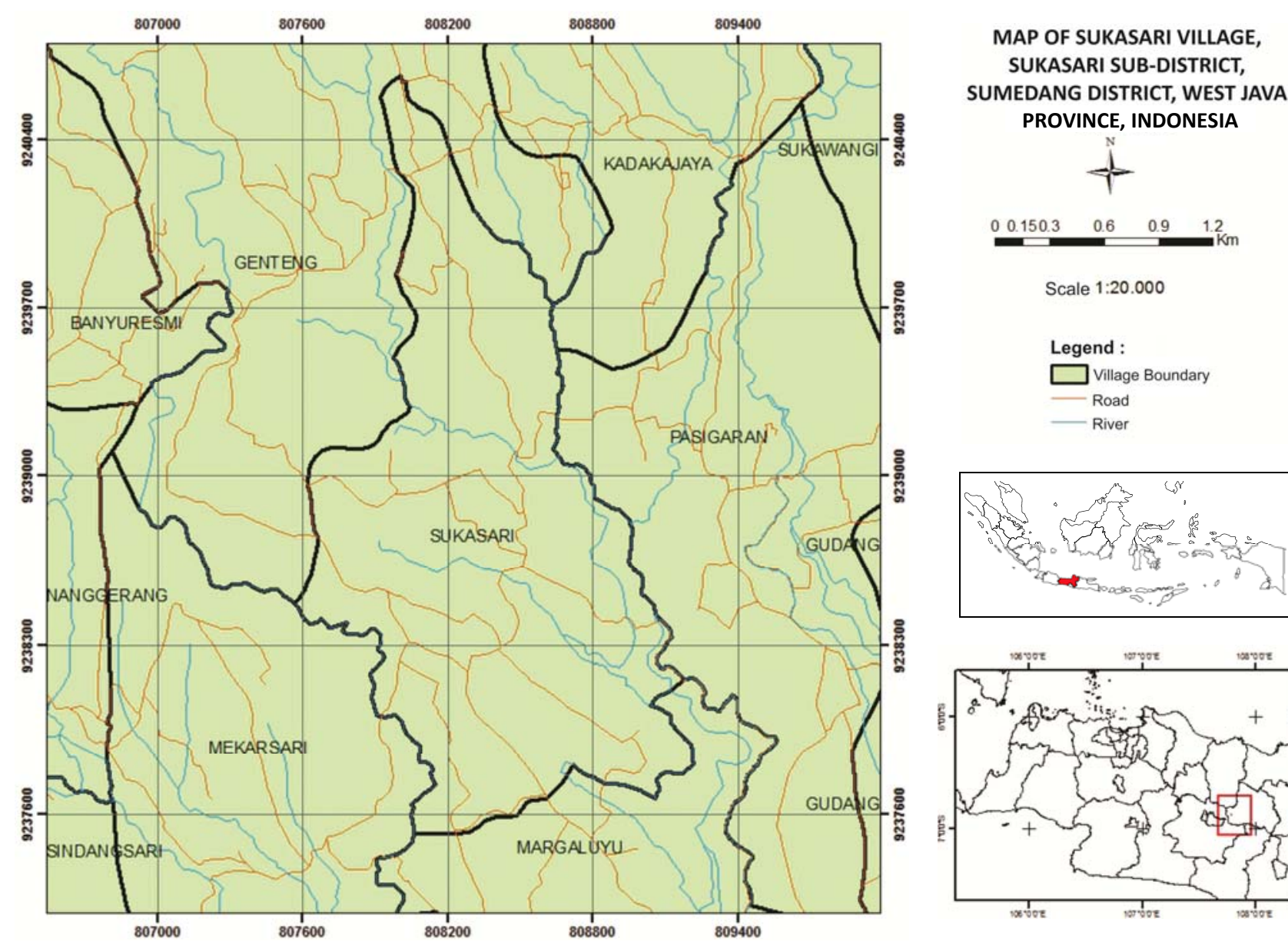

Scale 1:20.000

Legend :

$\square$ Village Boundary

Road

River
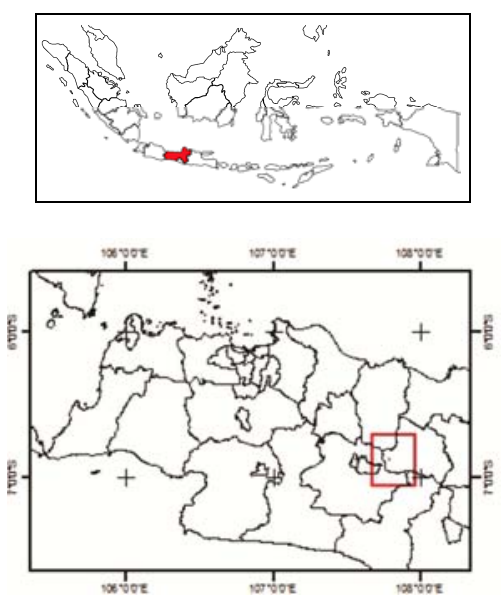

Figure 1. The map of Sukasari Village, Sumedang, West Java, Indonesia 
an estimated distance about $30 \mathrm{~km}$, then continue by 'ojeg' or 'angdes' for about less than half hour to reach the destination.

The agricultural system of Sukasari Village can be divided into two groups, namely the wet-rice field (sawah) and the dry-land field system that consists of homegarden (pekarangan), perennial mixed-garden (kebun campuran or talun), bamboo garden (kebun bambu), and annual crop garden (palawija). The wet-rice field is predominantly planted by rice crops while alternated by tobacco during the dry season. The tobacco cultivation, however, is predominantly undertaken in the dry field.

The registered population of Sukasari Village in 2006 was 1,711 households, with a total population of 4,937 individuals consisting of 2,477 males and 2,460 females. The population has increased over time which is determined by the death rate, birth rate, in-migration, and out-migration rate. In 2016 the total population of Sukasari village was registered 4,937 individuals consists of 3,145 male individuals and 3,326 female individuals (Table 1). Therefore, between 2006 and 2016, the population of Sukasari Village has increased by 1,804 individuals.

The predominant occupation of people in Sukasari village are registered as farmers (59.88 \%) and farmerlabor (31.93 \%) (Table 2). The wet-rice field cultivation system is predominantly practiced by people for the subsistence purpose, while the tobacco farming is undertaken for the commercial purpose. It has been historically recognized that some areas of Tanjungsari Subdistrict, Sumedang District as a center of both tobacco farming and tobacco trading of West Java (Alamsyah 2011).

\section{Method}

The method used in this study was qualitative which is based on the ethnoecological and biological approach (Martin 1995, Cunningham 2001; Newing et al. 2011; Alburquerque et al 2014). Techniques to collect field data, include observation, participant observation, and interview. The observation was undertaken in the field, particular observation of the ecological condition of tobacco gardens, tobacco crops, and activities of farmers in managing of tobacco crop and processing of tobacco productions. The observation participation was carried out by involving researchers in various activities of farmers in managing the tobacco farming, including planting and harvesting of tobacco in the gardens, and processing of tobacco production in the farmer houses. While the interview was applied with deep interview or semi-structured-interview with local experts or competent informants which are purposively selected by the snowball technique (cf. Martin 1995). Some informants were selected in this study, including old tobacco male and female farmers, female and male who are involved in the left tobacco, village middlemen, informal leaders, and formal village leaders.

The collected data was analyzed by crosschecking, summarizing, synthesizing, and built up a narrative with descriptive analysis and evaluative (cf. Newing et al. 2011).
Table 1. Number of household and people of Sukasari Village, Sumedang, West Java, Indonesia

\begin{tabular}{lcccc}
\hline $\begin{array}{l}\text { Sub- } \\
\text { hamlet } \\
\text { (RW) }\end{array}$ & Household & Male & Female & $\begin{array}{c}\text { Male } \\
\text { and } \\
\text { female }\end{array}$ \\
\hline 01 & 271 & 371 & 375 & 754 \\
02 & 217 & 342 & 301 & 643 \\
03 & 315 & 504 & 473 & 977 \\
04 & 187 & 265 & 235 & 498 \\
05 & 189 & 266 & 257 & 523 \\
06 & 172 & 212 & 246 & 458 \\
07 & 156 & 201 & 217 & 418 \\
08 & 147 & 206 & 206 & 412 \\
09 & 146 & 194 & 183 & 377 \\
10 & 102 & 129 & 134 & 263 \\
11 & 100 & 122 & 113 & 235 \\
12 & 238 & 321 & 314 & 635 \\
13 & 87 & 109 & 111 & 220 \\
14 & 128 & 265 & 158 & 323 \\
Total & 2458 & 3145 & 3326 & 6741 \\
\hline
\end{tabular}

Note: Pemdes Sukasari (2016)

Table 2. The main occupation of people of Sukasari Village, Sumedang, West Java, Indonesia

\begin{tabular}{lll}
\hline Main occupation & $\begin{array}{l}\text { People } \\
\text { number }\end{array}$ & $\begin{array}{l}\text { Percent of the } \\
\text { total (\%) }\end{array}$ \\
\hline Farmer & 1,500 & 59.88 \\
Farmer-labor & 800 & 31.93 \\
Trader & 62 & 2.47 \\
Worker/Employee & 50 & 1.99 \\
Civil servant/Indonesian & 18 & 0.71 \\
National Army & & \\
Entrepreneur & 75 & 2.99 \\
\hline Note: Pemkec Sukasari (2016) & &
\end{tabular}

\section{RESULTS AND DISCUSSION}

\section{Variations of tobacco}

Tobacco crop (Nicotiana tabaccum L) of Family Solanaceae is traditionally named in vernacular name by people of Sukasari as bako in Sundanese or tembakau in Indonesian language. On the basis of the local knowledge, it has been known seven variations of tobacco crops, namely bako bibit nani, bako bibit sano, bako bibit juhana, bako bibit kedu hejo, bako bibit kedu nangka, himar, and aromanis. These tobacco variations are named after the first people who introduced the tobacco seeds to their village. For example, the tobacco variations have locally been named as Juhana, Nani and Sano due to these tobacco seeds which are firstly introduced by Juhana, Nani and Sano.

Although there are seven variations of tobacco, the predominant tobacco variations, bako bibit sano, babo bibit juhana, bako bibit kedu, and bibit nani are locally cultivated by farmers of Sukasari village. Four tobacco variations are traditionally classified based on phenotype, ecological characteristics, processing, and taste for smoking purposes (Table 3). On the basis of the phenotype, tobacco crops may be divided into morphological characteristics, namely leaf shape, leaf thickness, shape of 
leaf base, and leaf color (Figure 2). Based on ecological characteristics, the tobacco variation can be divided into two categories, namely bako mole beureum (red tobacco) and bako mole bodas (white tobacco). The bako mole beureum consists of bako bibit kedu hejo and bako bibit nani are considered to be appropriately cultivated in the wet season, in a special area of upland, cold temperature, and light sandy loam soil. While the bako mole bodas consists of bibit bako sano and bibit bako juhana that is appropriately cultivated in the wet season with special are of low-land, cool temperature, and stony soil. In terms of cultivation systems, bako mole beureum is mainly provided with urea fertilizer, while bako mole bodas is mainly applied with NPK fertilizer. While based by the processing and taste, the tobacco can be traditionally divided into two types. The first type is traditionally considered as strong taste with strong aromatic and the second one is considered as light taste accompanied with less or no aroma. The strong taste and aroma is produced from mole beureum, while the light taste and non-aroma is produced from the mole bodas. The bako mole beureum is mainly processed when the tobacco namely leafs are placed in the house and are allowed to dry (dipeuyeum) between 3 and 4 days to get yellow leaf.Afterwards, the tobacco leafs are finely sliced, further dried, and then further moistened by dew (diibun). As a result, the tobacco has a strong taste of tobacco and aromatic. While the bako mole bodas is mainly processed by placing it in the house for 2 or 3 days. In addition, the tobacco leafs are roughly sliced, dried shorter and less moistened by dew. Consequently, it results in the light taste and non-aromatic tobacco.

The research has similar results to the report by Djajadi (2015) noting that some tobacco variations are traditionally farmed by tobacco farmers of Sumedang and Garut of West Java. He reported that the tobacco variations namely bako mole Nani, Kedu Omas, Kedu Hejo, Leuwiliang, Dasep, Adung, Nani Kanceh, and Kenceh Darawati are predominantly cultivated by farmers of Sumedang and Garut, West Java.

\section{The tobacco farming}

People of Sukasari Village have cultivated tobacco crop both in their village and neighboring villages at the same sub-district or different sub-district areas, including Jatinngor Sub-District. The tobacco are cultivated in agricultural lands located in their village, also in other villages by renting or share-cropping from other farmers of others villages. Traditionally, they have predominantly farmed tobacco in the dry land (lahan kering or tegal) although sometimes, cultivated in the wet-rice field (sawah), particularly in the rain-fed rice field (sawah tadah hujan) strictly in the dry season.

The cultivation of tobacco in the dry land is undertaken in both the wet-season and dry season. In the wet season, the planting tobacco is carried out in between October and November or December depending on the beginning of the rainy season. The tobacco is available for harvest between 3 to 4 months after planting. Therefore, it is usually harvested in December, January or February. While in the dry season, the tobacco is planted around March then harvested by June, but it may shift either earlier or later depending on the rainy season. After harvesting the tobacco, sometimes the land is altered by planting annual crops (palawija), including jagong/corn (Zea mays L), kacang tanah/peanut (Arachys hypogaea ), bonteng/cucumber (Cucumis satvus L), cabe/chili (Capsicum annum L), and kacang/beans (Phaseolus spp). The planting of palawija is usually in July and is harvested in September (Table 4).

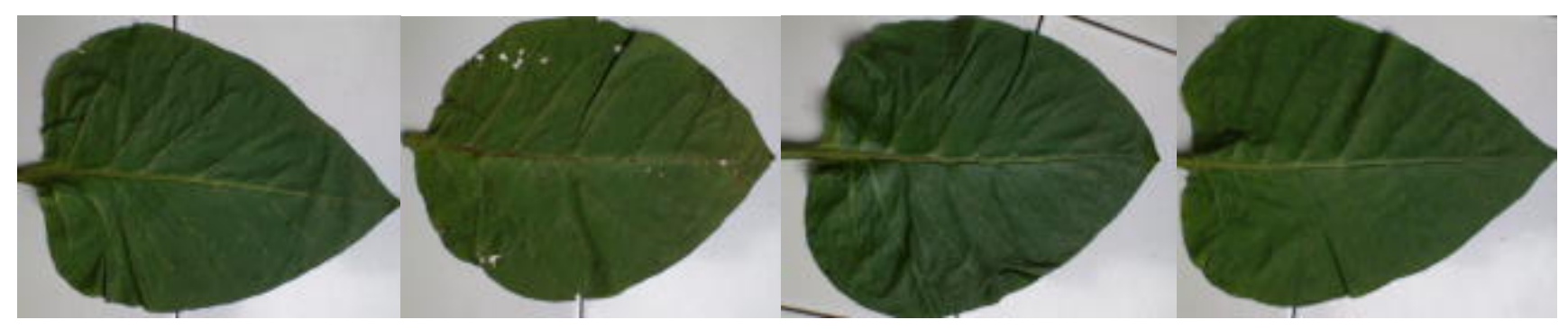

Figure 2. Variation of tobacco leafs, bako bibit juhana, bako bibit kedu hejo, bako bibit sano, and bako bibit nani are classified such as based on phenotypes, particularly leaf shape

Table 4. Tobacco cultivation at the dry field/garden (kebon) of Sukasari Village, Sumedang, West Java, Indonesia

\begin{tabular}{|c|c|c|c|c|c|c|c|c|c|c|c|c|}
\hline \multirow{2}{*}{ Crops } & \multicolumn{12}{|c|}{ Months*) } \\
\hline & Jan & Feb & Mar & Apr & May & Jun & Jul & Aug & Sep & Oct & Nov & Dec \\
\hline Tobacco & h-XXXx & & & & & & & & & p-Xxx & $\mathbf{X X X X}$ & $\overline{\mathbf{X x x x}}$ \\
\hline Palawija & & & & & & & p-XXX & $\mathbf{x x x x}$ & h-xxx & & & \\
\hline Tobacco & & & p-xxx & $\mathbf{x x x x}$ & $\mathbf{X x x x}$ & h-Xxx & & & & & & \\
\hline
\end{tabular}

Notes: p-xx=planting; h-xxh=harvesting. ${ }^{*}$ ) It will change depending on the rainy season 
Table 3. Variation of tobacco crops based on tobacco farmers of Sukasari Village, Sumedang, West Java, Indonesia

\begin{tabular}{|c|c|c|c|c|c|c|}
\hline \multirow{2}{*}{$\begin{array}{l}\text { Variation of } \\
\text { tobacco }\end{array}$} & \multirow[b]{2}{*}{ Leaf shape } & \multicolumn{2}{|c|}{ Phenotype/morphology } & \multirow[b]{2}{*}{ Leaf color } & \multirow[b]{2}{*}{ Ecology } & \multirow[b]{2}{*}{ Processing and taste of tobacco for smoking } \\
\hline & & Leaf thickness & $\begin{array}{c}\text { Shape of leaf } \\
\text { base }\end{array}$ & & & \\
\hline Mole bibit sano & Jorong (oval) & Kandel (thick) & $\begin{array}{l}\text { Berombak (wavy } \\
\text { shape) }\end{array}$ & $\begin{array}{l}\text { Hejo koneng } \\
\text { (green yellowish) }\end{array}$ & $\begin{array}{l}\text { Planted in the dry season of the } \\
\text { slight low land with cool } \\
\text { weather }\end{array}$ & $\begin{array}{l}\text { Placedtobacco leafs that are allowed to dry in the } \\
\text { slightly short between two and three nights, more } \\
\text { rough chopped, condensed in a shorter evening day, } \\
\text { and less strong taste and less aromatic }\end{array}$ \\
\hline $\begin{array}{l}\text { Mole bibit } \\
\text { juhana }\end{array}$ & Jorong (oval) & Ipis (thin) & $\begin{array}{l}\text { Berombak (wavy } \\
\text { shape) }\end{array}$ & Hejo (green) & $\begin{array}{l}\text { Planted in the dry season of the } \\
\text { slight low land with cool } \\
\text { weather }\end{array}$ & $\begin{array}{l}\text { Placed tobacco leafs that are allowed to dry in the } \\
\text { slightly short between two and three nights, more } \\
\text { rough chopped, condensed in a shorter evening day, } \\
\text { and less strong taste and less aromatic }\end{array}$ \\
\hline $\begin{array}{l}\text { Mole bibit kedu } \\
\text { hejo }\end{array}$ & $\begin{array}{l}\text { Buleud endog } \\
\text { (ovate) }\end{array}$ & Kandel (thick) & Rata (flat) & $\begin{array}{l}\text { Hejo koneng } \\
\text { (green yellowish) }\end{array}$ & $\begin{array}{l}\text { Planted in the wet season of the } \\
\text { upland with cold temperature }\end{array}$ & $\begin{array}{l}\text { Placed tobacco leafs that are allowed dry in the } \\
\text { slightly longer between three and four nights, more } \\
\text { finely chopped, condensed in the evening dew longer, } \\
\text { and strong and aromatic cigarette taste. }\end{array}$ \\
\hline Mole bibit nani & Jorong (oval) & Kande (thick) & $\begin{array}{l}\text { Berombak (wavy } \\
\text { shape) }\end{array}$ & $\begin{array}{l}\text { Hejo koneng } \\
\text { (green yellowish) }\end{array}$ & $\begin{array}{l}\text { Planted in the wet season of the } \\
\text { upland and with cold } \\
\text { temperature }\end{array}$ & $\begin{array}{l}\text { Placed tobacco leafs that are allowed to dry in the } \\
\text { slightly longer between three and four nights, more } \\
\text { finely chopped, condensed in the evening dew longer, } \\
\text { and strong taste and aromatic cigarette. }\end{array}$ \\
\hline
\end{tabular}


Table 3.Main stages of tobacco cultivation of Sukasari Village, Sumedang, West Java, Indonesia

\begin{tabular}{|c|c|c|c|c|}
\hline $\begin{array}{l}\text { Seed selection } \\
\text { (milih binih) }\end{array}$ & $\begin{array}{c}\text { Nursery preparation } \\
\text { (ipukan) }\end{array}$ & $\begin{array}{l}\text { Land preparation of tobacco } \\
\text { garden (nyiapkeun kebon) }\end{array}$ & $\begin{array}{l}\text { Cultivation of tobacco } \\
\text { (ngebon bako) }\end{array}$ & $\begin{array}{l}\text { Tobacco processing } \\
\text { (ngolah hasil bako) }\end{array}$ \\
\hline $\begin{array}{l}\text { Selecting individual good } \\
\text { flowering tobacco at the garden }\end{array}$ & Nursery in the paranggong & Nyacar/ngababad (shrub cutting) & $\begin{array}{l}\text { Ngaseuk jeung melak (making } \\
\text { holes by wood dibbling stick and } \\
\text { transplanting) }\end{array}$ & $\begin{array}{l}\text { Meuyeum (allowing tobacco leafs } \\
\text { to dry) }\end{array}$ \\
\hline $\begin{array}{l}\text { Harvesting the flowering and } \\
\text { selecting tobacco seeds }\end{array}$ & Making paranggong & $\begin{array}{l}\text { Ngagaringan (dryingvegetation } \\
\text { shrub biomass) }\end{array}$ & Nurub (shading) & Nyebit (tearing off of midribs) \\
\hline Drying the seeds & $\begin{array}{l}\text { Put good soil and humus in the } \\
\text { paranggong }\end{array}$ & Dihuru (burning) & Mupuk/ngagemuk (manuring) & Ngaleleng (rolling) \\
\hline $\begin{array}{l}\text { Storing seeds in the bottles or } \\
\text { bamboo segments }\end{array}$ & Sowing the seed tobacco & Mencug (hoeing) & $\begin{array}{l}\text { Ngored jeung nyaeur (weeding } \\
\text { and repairing ridges) }\end{array}$ & Ngeureut (slicing) \\
\hline \multirow[t]{8}{*}{ Continued by nursery preparation } & $\begin{array}{l}\text { Giving water in the morning and the } \\
\text { afternoon }\end{array}$ & Ngalaci (furrowing) & Ngepel (severing the lowest level) & Ngicis (laying on the sasag) \\
\hline & $\begin{array}{l}\text { Moving to polybag and transplanting in } \\
\text { the tobacco garden }\end{array}$ & $\begin{array}{l}\text { Continued by cultivation of } \\
\text { tobacco }\end{array}$ & $\begin{array}{l}\text { Ngahileud jeung nyemprot hama } \\
\text { (killing caterpillars and spraying } \\
\text { pests) }\end{array}$ & Moe (sun-drying) \\
\hline & Nursery in the field & & $\begin{array}{l}\text { Naruk (nipping off inflorescence) } \\
\text { Nyirung (nipping off buds) }\end{array}$ & $\begin{array}{l}\text { Ibun (moisten with dew in several } \\
\text { nights) }\end{array}$ \\
\hline & Selection of the fertile soil block & & Ngala (harvesting) & Meungkeut (tying) \\
\hline & Hoeing and putting fertilizer & & $\begin{array}{l}\text { Nyabut tangkal (pulling tobacco } \\
\text { trees) }\end{array}$ & $\begin{array}{l}\text { Jual/ngical bako mole (selling } \\
\text { tobacco of mole) }\end{array}$ \\
\hline & Sowing the tobacco seeds & & $\begin{array}{l}\text { Cultivation of tobacco crops or } \\
\text { planting palawija }\end{array}$ & $\begin{array}{l}\text { Jual/ngical bako mole (selling } \\
\text { tobacco mole) }\end{array}$ \\
\hline & $\begin{array}{l}\text { Giving water in the morning and the } \\
\text { afternoon }\end{array}$ & & & \\
\hline & Transplanting in the tobacco garden & & & \\
\hline
\end{tabular}


Unlike the dry land, the cultivation of tobacco in the rain-fed rice field is undertaken only in the dry season. The tobacco is usually planted in April or May and harvested in July or August. Following the harvest of the tobacco, the land is cropped by paddy in the rainy season. Like Sukasari Village, the people of Salamungkal hamlet, Cigentur Village, Paseh Sub-district, Bandung District, West Java cultivate tobacco in the dry land. The tobacco is farmed at a particular plot for one to two years while mixed with corn. The tobacco is cultivated in March and harvested four months after harvesting (Igarashi 1985). However, unlike Sukasari Village and Salamungkal hamlet, the people of Pamekasan, Madura cultivate tobacco of local variation called prancak, namely in both tegal and sawah in between April and August (Hasan and Darwanto 2013). In general, the cultivation of tobacco is determined by weather and climate condition. Since the lack of water often causes a drought that hinders the growth of tobacco crops. Conversely, the tobacco cannot be properly processed due to a lot of rain and not enough sunlight (cf. Ihsannidin 2010).

In other words, the tobacco crops is sensitively determined by the local environment, such as weather conditions. In addition, the tobacco cultivation is also affected by the market economy, such as fluctuation of input and output prices (Larsito 2005). The tobacco cultivation, therefore, needs special knowledge and high attention (Mitchell 2016). Although the cultivation of tobacco has high risk, many farmers are involved in the tobacco farming due to the high benefit potentialfor providing the household a high income (Hasan and Darwanto 2013).

\section{Tobacco farming cycle}

There are five main stages of in the tobacco farming cycle, namely seed selection, nursery preparation, land preparation, tobacco cultivation, and tobacco processing (Table 3).

\section{Seed selection}

The preparation of tobacco seedling is traditionally undertaken by each household of the tobacco farmers. The seeds of tobacco are obtained from the previous harvest. First, some tobacco trees are selected that have very good quality. Second, the tobacco leafs of the selected tobacco trees are not allowed to harvest to keep a good quality of seeds. When the flower of the selected tobacco trees mature, its flowers are selectively harvested with a good quality. Third, the flowers are dried by sunlight for about 5 days, so that the seeds in the dried flower can be easily taken. Fourth, to acquire the seeds, the dried flowers of tobacco are motioned or blown. The tobacco seeds of good quality and uniform size which are not empty are selected. Fifth, the seeds are put in the bottle or bekong, a segment of bamboo that is covered by plastic. As a result, the tobacco seeds can be traditionally protected and durable for two planting season.

\section{Nursery preparation}

The seedbed preparation can be undertaken in two ways, namely in the homegarden and the dry land field to be planted tobacco. The seedbed preparation in the homegarden is undertaken with more care and will not cultivate to large area. First, to construct paranggong which is a kind of table made from bamboo with length about 3 meters and width about 1 meter. Second, the fertile land is put in the paranggong. Third, it is covered by humus of plant leafs. Fourth, the top is covered by the remaining residue of burned bamboo leafs (tai durukan). Fifth, the tobacco seeds in the bekong are sown in the soil at the ranggong. Sixth, before the tobacco seeds grow, the seedbed is provided with water in the morning and the evening. The provision of water is continuously undertaken approximately for 60 days. Seventh, the tobacco seedling age 60 days are then moved to a polybag, banana leaf or arenga leaf so that the seed will develop well and strong roots. After two weeks the tobacco seedling are stored in the polybags and transplanted in the dry land or the rainfed field.

The seedbed preparation in a particular plot of the dry land must also be undertaken in several stages. First the particular plot of fertile land is selected. In particular it is safe from livestock disturbances and strong wind. The selected plot of land is finely hoed (dipencug). Second, the soil is provided by fertilizers, such as compost. Third, the tobacco seeds are sown in the seedbed and provided water in the morning and evening. Fourth, the tobacco seedling aged 60 days are transplanted in the dry land field or the rainfed field.

\section{Land preparation and tobacco cultivation}

At the time waiting for the tobacco seedlings to be readily planted, the land preparation is undertaken before the rainy season. First, the trees are selectively slashed (dituar) by machete and undergrowths are cleaned (ngababad) by machete and knife. Between two and three weeks after the trees have been felled, all cut organic matter will have dried. The trash is collected into piles and burned (ngaduruk) to supplement nutrients in the soil also to kill insects, pests and weed populations (cf. Rambo 1984). Second, the land is hoed and furrowed into some plots with distance between plots about 1 meter. Third, the land of each plot is made holes (cogekan) with a distance between holes about $80 \mathrm{~cm}$. Fourth, each hole is provided by various manure (ngagemuk), such as dung of chicken sheep, goat, and cow. Fifth, after it is left about between 7 to10 days, tobacco seedlings are transplanted in to the holes after the wrapping areopened. Each hole is inserted with one individual of seedling. This tobacco transplanting work is undertaken in the evening to avoid strong sunlight radiation which may result in wilt.

\section{Managed prepared tobacco garden}

At the first week, the tobacco crops are regularly provided with water every day. However, in the next week, they are provided with water only twice each week. After 
one week from the transplanting, the tobacco crops are planted with inorganic fertilizers, such as NPK, Urea, or mixture of both. Before providing fertilizers, the land is firstly perforated by a dibble (aseuk) with distance about 10 $\mathrm{cm}$ to each tobacco tree. Moreover, the liquid fertilizer is inserted into each hole and repeated after two weeks. After the age of tobacco plants are about one month reaching a height about $30 \mathrm{~cm}$, ridges are repaired and the tobacco tree crops are put soil to produce strong growth trees.

After one month repair ridges (nyaeur), the number of tobacco leafs of each tree is counted. If the number tobacco leafs of each tree has about between 18 to 20 leafs, the shoots are cut (ditaruk) to properly grow and equitable grow. After cutting shoots, the underneath branches are cut. At the same time, the tobacco crops are maintained due to a lot of pest attack. Some tobacco pests, such as grasshopper/simeut (Family Acridae), tobacco horn worn/hileud (Manduca secta), bereng (Aphis sp), are predominantly found. The tobacco leafs are usually eaten by caterpillars, grasshoppers, and tobacco horn worm. As a result, the tobacco leafs are damaged. For example, the tobacco leafs have become perforated. To combat the pests are undertaken by farmers, by picking pesta and using pesticides. Like the wet rice cultivation, the pesticides are intensively used in tobacco farming. Consequently, the costs for buying pesticides have increased, but at the same time the pest has also exploded. Intensive use of pesticides often causes alot of natural enemies of pest to be killed and pests have become resistant (cf. Nurinda 2006; Thei et al 2013; Fox 2016; Winarto 2016).

\section{Harvesting}

After the cutting shoots are undertaken three times, the tobacco is considered ready to be harvested. Signs of the tobacco tree are ready to be harvested, include that two or three leaves have become yellowish and have white nodules and many stripes. Before starting tobacco leaf harvesting (diunduh), some preparations must be carried out. For example, bamboo plates (sasag) for drying tobacco leafs are made. Between 50 till 55 day after transplanting or 3 months after tobacco seed nursery are established, the harvest starts, beginning withthe lower leaves between one and three leafs that has bad quality (obreg). Then one week later, middle leaves are harvested, and finally upper leafs are harvested, these are considered to be best quality, because the ripening goes from the lower to upper. The upper leafs have been mature longer and the rarely obtain rainfall. As a result, it will produce good taste and aromatic. The harvest of tobacco leafs is usually undertaken in the morning after the dew on the leaves have dried. The young leafs are avoided to be accidentally harvested since it will result in bad quality of tobacco. Conversely, if harvested too old the tobacco leafs that will get bad color.

\section{Processing tobacco production}

The tobacco processing is traditionally undertaken in several steps. First, the tobacco leafs are cut and carried to homes. Second, the leaves are put in the sack and tied with a rope or wrapped by banana leafs. Third, tobacco leafs are placed and allowed to dry (dipeuyeum) for one to three nights to be yellowish and withered. One sack consist of 50 kilograms of tobacco leafs. Fourth, after one the withered leafs are torn off midribs (disebit or diroeh) by folding the leaves in half (Figure 3.A). As a result, the midrib of each leave can be discarded.

Fifth, the tobacco leafs are collected and carefully laid, and separated based on the quality. Sixth, the tobacco leafs are rolled (digulung) to be some pillow shapes. One pillow consists of 25 leaves. The biggest leafs, intact, and homogenous color are then separated and used as wrapped of leaf roll to be sliced (diiris or dirajang). After the leaf rolls are placed for one night the next day they are sliced by using knife (pisau rajang) at the rajangan (Figure 3.B). The slice process is appropriately undertaken at night starting from midnight to 10 o'clock a.m. since the sliced tobacco leafs can be directly dried.

The slice of tobacco leafs must be undertaken as smooth as possible. After the sliced leafs are sorted by women based on length. The short sizes are separated as low quality of tobacco. Moreover, sliced leafs are laid (diicis) on bamboo plates with has length $1 \mathrm{~m}$ and width $0,5 \mathrm{~m}$ that is called sasag or ebeg and its base is covered by fabric. Normally one roll of tobacco leafs is for sasag.The sliced tobacco leafs on sasag are carried on panagan made of bamboo at the homegarden (Figure 3.C).

After the tobacco is dried by sunshine and moisten with dew (diibun) from one night to three nights the tobacco takes a dark color. This work is very hard since if the tobacco gets rainwater, it may grow fungus and must be redried by sunshine to become dry. When the tobacco is moistening by dew it may produce the aromatic characteristics of tobacco. Moreover, the tobacco slabs are folded into three parts or wrapped by dried banana midrib and placed in the house for between one to two weeks. Finally, the product that is called bako mole is ready to be sold. Normally, each sasag plate of tobacco ties 20 sasag of tobacco and is made as one package for sale to middlemen (pengepul).

\section{Tobacco trading}

There are two emic categories by which the people of Sukasari Village divide the households in involving into the tobacco farming system, namely petani tembakau (tobacco farmers) and petani tembakau dan pengepul (mixed as tobacco farmers and village middlemen). The first category is recognized as farmers who involve in the tobacco farming. They are annually involved in various activities of tobacco cultivation systems, including seed selection, nursery preparation, land preparation, tobacco cultivation, and tobacco processing. While the second category is recognized and acknowledged as tobacco farmer which is similar to that of the first category they are involved in various activities of tobacco cultivation, but they are also involved in buying the tobacco products as middlemen. 


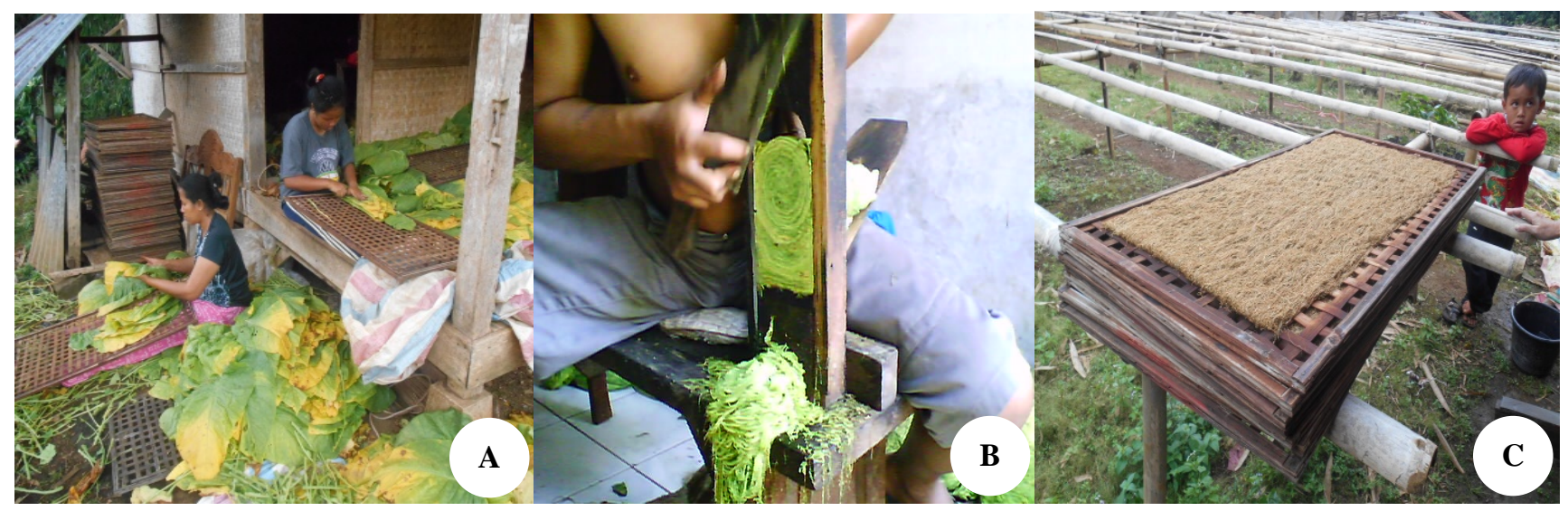

Figure 3.A. The tear off of the tobacco midribs (nyebit or ngaroeh). B. Slice leaf roll of tobacco (ngereut or ngarajang), C. Sun dry of the sliced tobacco leafs on sasag or ebeg

The farmers who are known as the first category, petani tembakau, have annually cultivated the tobacco cultivation for generations over time. The harvested tobacco leafs are usually processed by each household. The tobacco leafs processing activities, namely leafs are allowed to dry (meuyeum), tear off midribs (nyebit or ngaroeh), sliced (ngeureut), lay on sasag (ngicis), sun-dry (moe), and moisten with dew (ngibun) are undertaken by males and females. For example, nyebit,ngicis, moe, and ngibun are predominantly carried by males. While ngeureut (slice) is undertaken by males who own special knowledge and technique obtained by learning from their father. In other words, men know more knowledge and expertise in slicing (ngeureut) the tobacco leafs than women do since men intensly participate in their father activities, particularly in ngeueut (cf. Lizararralde 2004). Consequently, this knowledge and skill is not continuously inherited, if the nuclear family does not have sons. Indeed, the tobacco processing, particularly in relation with ngeureut the family will be seriously disturb.

Unlike the first category, the second category, petani tembakau dan pengepul, they are both involved in the tobacco cultivation and processing of production as well as involved in the trading of tobacco from other people, mainly from the first category (petani tembakau). Based on information of informants, it has been revealed that about 90 per cent of people Sukasari Village involve in the tobacco farming, and most of them act as the first category, while about only 13 households are recognized as middlemen (pengepul) to buy tobacco in their village.

Traditionally, two kinds of the folk tobacco (tembakau rakyat) are produced by people of Sukasari, namely bako mole beureum and bako mole bodas. The bakomole beureum is considered strong taste and aromatic, while the bako mole putih is considered as light taste and nonaromatic. The people of Sukasari as other tobacco farmers of West Java predominantly produce bako of bako mole as bako sambaraan that need processing namely condiments and readily sold. The low quality tobacco, traditionally named bako mole bodas, produced by each household of
Sukasari Village is usually sold to local middlemen (pengepul). Moreover, the bako mole products are carried by pengepul to be sold to other middlemen in other districts of West Java, such as Tasikmalaya, Garut, and Cianjur that tobacco mole bodas products are applied spice (disamaraan), packed, then sold to consumers. The high quality of tobacco, locally named bako beureum from each household are sold to local middlemen, then the bako beureum that has been collected by some middlemen are sold to the tobacco factories, such as BAT, Sampurna, and Gudang Garam. The selling of bako mole beureum, however, is annually sold in between August and November, due to the tobacco products having highly demanded by factories at that time. About 2 tons of bako mole beureum from the Sukasari Village are transported for each two weeks to tobacco factories in Central Java and West Java between August and November. In other words, the bako mole beureum are traditionally sold by the group of local middlemen to tobacco factories only in certain time, namely when the tobacco factories 'membuka' (open to) buying the folk tobacco. In addition, the local middlemen usually sell bako mole beureum when the price of tobacco has a high price. As a result, if the tobacco price low, the bako mole beureum products are stored in the house and it will sell later if the tobacco price has increased.

The tobacco farming system of Sukasari Village has been determined by socio-economic and ecological factors (cf. Rambo and Sajise, 1984; Brush 2000; Futri et al. 2005; Ridwan 2009; Fauziyah 2010; Hasan and Darmanto 2013; Masruroh 2015). The socio-economic factors consist of local knowledge, technology, capital, and market; while the environmental factors, such as soil fertility, water, pest, and climate. Unlike the wet-rice field as subsistence economy, the tobacco farming has been predominantly practiced for the commercial purpose to provide cash income for the household. As a result, the tobacco farming systems have been dynamically influenced by market economy. For example, the cause of increasing various pests of tobacco farming due to the frequent climate anomalies results in an 
increase cost of buying pesticides. Conversely, since the pesticide use has increased, the pest has increased due to the pest gaining resistant to the pesticides and a lot of natural enemies of pest are killed (cf. Fox 2016; Winarto 2016). Indeed, predominant of climate anomalies in the last several decades, has seriously influenced the tobacco farming. For example, since the length of the rainy season has frequently increased, the quality of tobacco is low producing low prices of tobacco as well as reduce in the household income. In addition, because the agricultural land areas that have decreased due conversion to other land-uses, the tobacco farming systems as source of income are disturbed. The fluctuation of the selling price of tobacco has also become constraints for the tobacco farming. In terms of local knowledge, the Sukasari peoples tobacco farming systems, including the processing of tobacco leaf slice has eroded and may extinct in the near future since neglected by younger generations.

The tobacco farming systems have been considered a high risk. Since the tobacco farming systems have been influenced by various ecological and socio-economic factors. Many farmers of Sukasari, Sumedang, however, have predominantly involved in the tobacco farming, to provide the household an income. Based on this study, it can be concluded that the Sukasari, Sumedang have various local ecological knowledge in relation with practicing of the tobacco farming system, including various tobacco crops (land races), cultivation and processing of tobacco. There are 4 tobacco variations, namely bibit kedu hejo, bibit ani, bibit sano, and bibit juhana that produce the folk tobacco, called bako mole bodas and bako mole beureum are predominantly planted by the people. These tobacco variations are planted in the dry land and rainfed field that are managed through five main stages, including seed selection, nursery preparation, land preparation, tobacco cultivation, and tobacco processing which are based on the local ecological knowledge. The folk tobacco productions of tobacco are traditionally sold to local middlemen, then sold to outer village middlemen, and tobacco factories.

\section{ACKNOWLEDGEMENTS}

This research was supported by the program of Academic Leadership Grant (ALG) of Prof. Johan Iskandar, funded by the Padjadjaran University, Sumedang, Indonesia. Therefore, on this occasion we would like to thank Prof. Tri Hanggono Achmad, who provided ALG.

\section{REFERENCES}

Alamsyah AR. (ed). 2011. Black-White of Tobacco. UI Press, Depok. [Indonesian]

Albuquerque UP, da LVFC, de Lucena RFP. 2014. Methods and Techniques in Ethnobiology. Springer, New York.

Arnez M. 2009. Tobacco and Kretek: Indonesia Drugs in Historical Change. ASEAS: Österreichische Zeitschrift für Südostasienwissenschaften 2 (1): 49-69.

Azril 2007. Study on varieties and management and using of tobacco in Sukasari Village,Sumedang. [Internal Report]. Study Program of Biology, Padjadjaran University, Sumedang. [Indonesian].
Bannister K, Barrett K 2004. Weighing the Proverbial "Ounce of Prevention" again the "Pound of Cure" in a Biocultural Context: A Role for the Precautionary Principle in Ethnobiological Research. In Carlson TJS and Maffi L (eds), Ethnobotany and Conservation of biocultural diversity. The New York Botanical Garden Press, Bronx, New York.

Berkes F, Colding J, Folke C. 2000. Rediscovery of traditional ecological knowledge as adaptive management. Ecol Appl 10: 1251-1262.

Boomgaard P. 2002. Corn and Tobacco in Uplands of Indonesia 16001940. In Li TM (ed). Transforming the Indonesian Uplands: Marginality, Power and Production. Yayasan Obor Indonesia, Jakarta. [Indonesian]

Brush SB. 2000. Ethnoecology, Biodiversity, and Modernization in Andean Potato Agriculture. In Minnis PE (ed), Ethnobotany: Reader. The University of Oklahoma Press, Oklahoma.

Cakrabawa DN, Nuryati L (eds). 2014. Otlook of Tobacco Comodity. Data Center and Agricultural Information System, General Secretariat of Agricultural Ministry, Jakarta. [Indonesian].

Cotton CM. 1996. Ethnobotany Principles and Application. John Wiley and Sons Ltd, West Sussex, England.

Cunningham AB. 2001. Aplied Ethnobotany: People, Wild Plant Use \& Conservation. Earthscan Publication Ltd, London and Sterling Va.

Djajadi D. 2015. Tobacco diversity in Indonesia. J Biol Res 20: 27-32.

Ellen R. 2002. 'Déjà vu, all over again', again: Reivention and progress in applying local knowledge to development. In Sillitoe P, Bicker A, Pottier J (eds), Participating in Development Aproahes to Indigenous Knowledge. Routledge, London.

Elson RE. 1994. Village Java under Cultivation System 1830-1870. Allen and Unwin, Sydney.

Fauziyah E. 2010. Analysis of tobacco farming production in Pamekasan District. Jurnal Organisasi dan Managemen 6 (2): 119-131 [Indonesian]

Ford RI. 2000. Agriculture An Introduction. In Minnis PE (ed), Ethnobotany A Reader. University of Oklahoma Press, Oklahoma.

Fowler CS. 2000. Ethnoecology: An Introduction. In Minnis PE (ed), Ethnobotany A Reader. University of Oklahoma Press, Oklahoma.

Fox JJ. 2016. Insects that multiply rapidly threatening the production of rice in Java. In: Winarto YT (ed), Food Crises and Fallacy: why is this continues? Yayasan Obor Indonesia, Jakarta. [Indonesian]

Geertz C. 1963. Agricultural Involution: The Processes of Ecological Change in Indonesia. University of California Press, Bekeley, Los Angeles, and London.

Hasan F and Darwanto DH. 2013. Prospects and chellenges of tobacco farming in Madura. SEPA 10 (1): 63-70 [Indonesian].

Igarashi T. 1985. Chapter 1. Some Notes on the Subsistence in A Sundanese Village. In Suzuki S, Soemarwoto O, Igarashi T. (eds). Human Ecological Survey in Rural West Java in 1978 to 1982. Nissan Science Foundation, Tokyo.

Ihsannudin 2010. Risk of Tobacco Farming in Magelang District. Embryo 7 (1): 21-28 [Indonesian].

Iskandar J, Iskandar BS, Partasasmita R. 2016. Responses to environmental and socio-economic changes in the Karangwangi traditional agroforestry, South Cianjur, West Java. Biodiversitas 17 (1): 332-341.

Karim R, Nahar N, Shirin T, Rahman MA. Study on Tobacco Cultivation and its Impacts on Health and Environment at Kusthia, Bangladesh. J Biosci Agric Res 8 (2): 746-753.

Larsito S. 2005. Benefit analysis of to rural community tobacco farming and relative economic efficiency relative to scale arable cultivate land: Study case in Gemuh District Kendal. [Thesis] Master Study Program of Economic and Development Biology, Padjadjaran University, Sumedang. [Indonesian].

Lizarralde M. 2004. Indigenous knowledge and Conservation of Rain Forest: Ethnobotany of the Bari of Venezuela. In Carlson TJS, Maffi L. (eds), Ethnobotany and Conservation of Biocultural Diversity. The New York Botanical Garden Press, Bronx, New York.

Maffi L. 2004. Maintaining and Restoring Biocultural Diversity: The Evolution of a Role for Ethnobiology. In Carlson TJS, Maffi L. (eds), Ethnobotany and Conservation of biocultural diversity. The New York Botanical Garden Press, Bronx, New York.

Martin GJ. 1995. Ethnobotany: a Methods Manual. Chapman and Hall, London.

Masruroh A. 2015. Contribution of Tobacco Farming contributes to household income in Salamrejo Village Selompang Subdistrict Tumenggung Central Java. [Hon. Thesis]. Study Program of 
Economic Education, Faculty of Economy, Universitas Negeri Yogyakarta, Yogyakarta [Indonesian].

Mitchell MC. 2006. The Political Economy of Tobacco in Indonesia: How "Fires Fell Upon the Earth". Thesis]. George Mason University, Fairfax VA.

Newing H, Eagle CM, Puri, Watson CW. 2011. Conducting Reaearch in Conservation: Social Science Methods and Practice. Routledge, London.

Nurindah 2006. Agroecosystem Management in pest control. Perspektif 5 (2): 78-85. [Indonesian].

Pemdes Sukasari. 2016. Statistical data of Sukasari Village in 2016. Sukasari, Sumedang. [Indonesian]

Pemkec Sukasari. 2016. Statistical data of Sukasari Sub-district in 2016. Sukasari Village in 2016. Sukasari, Sumedang. [Indonesian]

Puri RK. 1997. Hunting knowledge of the Penan Benalui of East Kalimantan. [Ph.D Dissertation]. The Department of Anthropology at the University of Hawaii.

Purseglove JW. 1987. Tropical Crops: Dicotyledons. Longman, Singapore.

Putri EA, Suwandari A, Rijal JA. 2015. Analysis of Income and cost efficiency of tobacco farming Maesan 2 in Bondowosi. JSEP 8 (1): 64-69. [Indonesian].
Rambo AT 1984. No Free Lunch: A Reexamination of the Energetic Efficiency of Swidden Agriculture. In Rambo AT and Sajise PE (eds), An Introduction to Human Ecology Research on AgriculturalSystems in Southeast Asia. East West Center, Honolulu, Hawaii.

Rambo AT, Sajise PE. 1984. Introduction: Human Ecology Resaerch on Tropical Agriculture in Southeast Asia. In Rambo AT and Sajise PE (eds), An Introduction to Human Ecology Research on AgriculturalSystems in Southeast Asia. East West Center, Honolulu, Hawaii.

Ridwan. 2009. Food security of farmer households according to types of agroecosystem in Jerowaru District, East Lombok Regency. Agrteksos 19 (3): 155-164 [Indonesian].

Sillitoe P. 2002. Globalizing indigenous knowledge. In Sillitoe P, Bicker A, Pottier J (eds), Participating in Development Aproahes to Indigenous Knowledge. Routledge, London.

Thei RSP, Abadi AL, Mudjiono G, Suprayogo D. 2013. Study of athropod communities in a virginia tobacco agro-ecosytem. J Trop Life Sci 3 (2): $138-142$

Winarto YT. 2016. Farmers who are marginalized: Fallacy why they occur?. In: Winarto YT (ed), Food Crises and Fallacy: why is this continues? Yayasan Obor Indonesia, Jakarta. [Indonesian] 